\title{
Professional and communicative foreign language competence of future teachers
}

\author{
Valentina Panfilova ${ }^{1}$, Alexej Panfilov ${ }^{1}$, Alfia Gazizova ${ }^{3,1 a}$ and Nataliya Samarina ${ }^{4}$ \\ 1,2 Kazan Federal University, Russia, 423600, Elabuga, Kazanskaya St., 89 \\ ${ }^{3}$ Kazan Federal University, Russia, 423810, Naberezhnye Chelny, pr. Mira, 68/19 \\ ${ }^{4}$ Kalashnikov Izhevsk State Technical University, Russia, 427960, Sarapul, Krasnoarmeiskaya St., 93
}

\begin{abstract}
Studying of foreign-language competence at the present stage of higher pedagogical education development acquires the increasing relevance. In this paper the requirements of federal educational standards of pedagogical education and teacher' professional standard to forming students' foreign language competence mastering non-linguistic pedagogical specialties are specified. Analysis of understanding of professional and communicative foreign language competence by researchers has been performed; the author's structure of future pedagogues' foreign language competence is presented. The following subcompetences are distinguished as its structural components: linguistic, discursive, colloquial, pragmatic, information-technological, strategic, socio-cultural, personal-creative. The results of the foreign language competence level of the first and second year students of non-linguistic pedagogical specialties are shown. It is determined that the key structural elements of students' foreign language competence are within the advanced level of development. The strategic sub-competence is in a zone of optimal development level that makes actual creation of the psychological and pedagogical conditions for their development.
\end{abstract}

Keywords: Foreign language competence, structural elements of foreign language competence, subcompetence

\section{Introduction}

\subsection{The problem of future teachers' foreign language competence}

New requirements for the quality of school education, Federal state educational standards and teacher' professional standard suggest the need for changes in organization, content, technology, and the scale of teacher training in educational institutions.

\footnotetext{
${ }^{\text {a }}$ Corresponding author: Alfgazva@mail.ru
} 
The current Federal state education standard of higher education according to the academic bachelor program 44.03.01 - Pedagogical education calls for the revision of approaches to foreign language training of future teachers. Practical language skills not only as a language of international communication, but also as a means of professional and personal development are becoming increasingly relevant. It is the universal competence of future teachers that should be mastered: "...able to communicate in oral and written forms in Russian and foreign languages for solving tasks of interpersonal and intercultural interaction" [3]. It actualizes the development of foreign language professional and communicative competence of future teachers, which in its turn generates the need to clarify working definitions, structure of the studied competence and establish its relationship with the readiness to use foreign language opportunities for self-education and professional activities. Teacher' professional standard is defined as "the use of foreign language sources of information, translation tools, pronunciation together with the students" [14].

\subsection{View on foreign language professional communicative competence}

The study of professional communicative foreign language competence (PCFLC) is becoming increasingly important at the present stage of higher pedagogical education. PCFLC has been the subject of research studies of M.K. Kabardov [6], A.V. Khutorskoy [7], I.A. Zimnyaya [18], N.A. Proshjanz [17], I.I. Galimzyanova [4], A.I. Kurpesheva [9], M.D. Ilyazova [5], A.S. Andrienko [1], E.B. Mikhaylova [11]. As for T.A. Kostyukova, A.L. Morozova, it is not enough to be limited to linguistic and sociolinguistic aspects of foreign language competence, without paying proper attention to the professional orientation of future specialists' language training [8]. According to E.G. Nikitina, professional-foreign language competence is considered as the unity of three components: motivational-value; cognitive-pragmatic and emotional [13]. In studies of E.I. Baguzina the following foreign language components are specified: linguistic, discursive, strategic, socio-cultural, pragmatic and personal ones [2].

So, the analysis of studies show that foreign language competence is considered as a complex, multicomponent phenomenon, and scientists focus on the professional orientation of foreign language competence of future specialists. Non-linguistic competence is defined by authors differently, as "knowledge, skills and abilities", "abilities", "integrative personal and professional phenomenon ".

\subsection{Author's understanding of professional and communicative foreign language competence}

Structurally-substantial models of foreign language competence, despite common structural components, also have differences. There is a significant variability in component composition of foreign language competence, which is associated with the complexity and multidimensionality of foreign-language communication process. There is a need to identify the author's model of PCFLC of future teachers $[15,16]$. At the heart of the author's model are the thesis of the importance of its professional orientation and singling out its components as separate subcomponents.

We understand PCFLC as an integrative personal and professional phenomenon that determines the ability and willingness of the student to creatively solve practice-oriented information and communication tasks in professional activities as well as tasks of professionally oriented communication with native speakers in corresponding environment. We distinguish sub-competences as PCFLC structural components: linguistic (mastering vocabulary, grammar, phonetics, orthography): discursive (mastering logical organization 
of speech and written texts); colloquial (ability to speak coherently, without effort, at natural tempo, without long pauses for seeking the linguistic forms in receiving and transmitting professional information); pragmatic (ability to deliver the communication content according to the social context); information-technological (ability to search for professionally relevant information from different sources, efficiently use the foreign language Internet-resources in professional activity); strategic (ability to use the verbal and nonverbal professional communication strategies for compensation of the missing knowledge in real linguistic communication); socio-cultural (knowledge of the sociocultural context where the language is used, ability to establish the foreign language professional communication adequately); personal-creative (ability to increase the level of the foreign language proficiency, ability to self-development in research and creative activity).

\section{Purpose and methods}

The study determined the initial level of future teachers' PCFLC. As a subject of study the structural parts, criteria, indicators, evaluation methods of PCFLC were identified. Fixation of monitoring and evaluation of students' speaking and writing skills were conducted with the help of authors" "Students' linguistic competence assessment map".

The level of each sub-competence development was estimated according to the 10-point scale: "8-10" - high level of motivation, knowledge, skills, abilities and abilities, "6-7" - the advanced level, "3-5" - the optimal level, "1-2" - the initial level. The final level of PCFLC development was defined as the arithmetic mean obtained during the expert evaluation of students' performance in various types of assignments. Each subcomponent consists of cognitive, operational-effective, emotional, motivational-value and reflective components.

Linguistic and communicative tests, and peer assessment of students' speaking skills were applied in study of cognitive component of students' foreign language competence. Studying operational-efficient PCFLC component the communicative tests were applied, as well as expert assessment of speech and writing activity that evaluated the structural elements such as linguistic, conversational, pragmatic, information technological, strategic, socio-cultural and personal-creative ones. The final data were recorded in the observation maps and estimated as the arithmetic mean of the grades obtained while studying the researched competences.

Observing motivational-value PCFLC component the adapted methodology by M.I. Lukyanova and N.V. Kalinina was used [10]. The investigation of the emotional and reflexive PCFLC components was based on self-regulation method and evaluation of the training-professional activity [12].

\section{Results}

The first and the second year students of non-linguistic pedagogical specialties (739 students, bachelor level program "Pedagogical education") took part in the study of initial level of PCFLC structural elements. At the first research stage the students that demonstrated high level of foreign language skills according to the results of practice tests were identified (120 students, that makes $16,2 \%$ of the total sample). In the second stage the results reflecting the intensity level of each sub-competence were obtained. The average values of the indicators in groups were determined (Figure 1). 


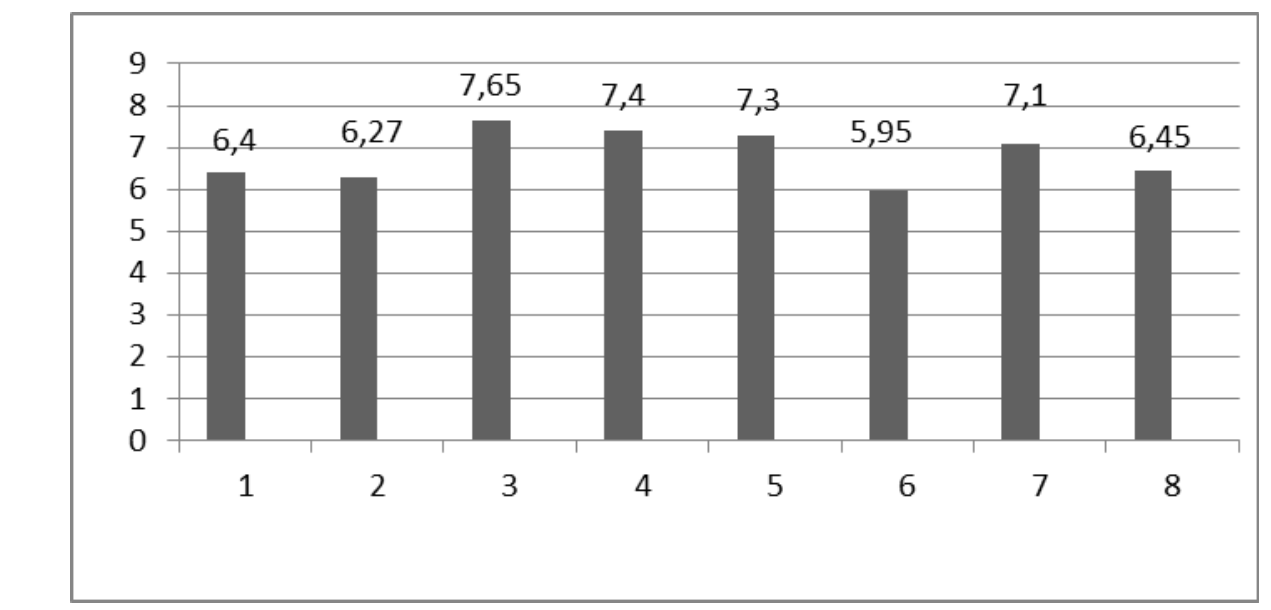

Conventional signs: 1. Linguistic subcompetence. 2. Discursive subcompetence.3. colloquial subcompetence. 4. Pragmatic subcompetence. 5. Information technological subcompetence. 6. Strategic subcompetence. 7. Sociocultural subcompetence. 8. Personal-creative subcompetence.

Figure 1. The initial level of future teachers' PCFLC

The analysis showed that most of the PCFLC structural elements fall within the area of the advanced development level - from 6,07 to 7,65 points. Higher level was identified in respect of the colloquial sub-competence representing the students' ability to speak coherently, without strain, at natural tempo, without long pauses for seeking the linguistic forms in exchanging professional information - 7,65 points; as well as the pragmatic subcompetence representing the student's ability to deliver the communication content according to the social context $-7,4$ points. The strategic sub-competence representing the ability to use verbal and nonverbal communication strategies - 5,95 points. Thus, at the optimal level are the skills associated with the linguistic creativity of students, as the ability to show creativity when writing a report or a business letter (5.4 points); the ability to display the variability and uniqueness of speech solutions in oral speech and in written texts (5.8 points).

While analyzing the obtained data, the initial level of PCFLC components (cognitive, operational-effective, emotional-volitional, motivational-value and reflective components) as the arithmetic mean of indicators in studied group of students was defined (Figure 2).

\section{Discussion}

Analysis of future teachers' PCFLC components allows to conclude that the cognitive component reflecting professional and linguistic knowledge is at the advanced level of development (72,3 points), as well as the operational effective component, reflecting the ability to implement professional language communication (68,7 points), motivational and value component, reflecting educational and professional motives and values is 63,8 points. The highest level on cognitive component development was identified, that shows the dominance of "knowledge" model in foreign language learning. The PCFLC reflective component, representing the capacity to introspect, the ability to determine own educational route (set goals, bear responsibility for the final result of mastering foreign language) showed the optimal level (57,8 points). 


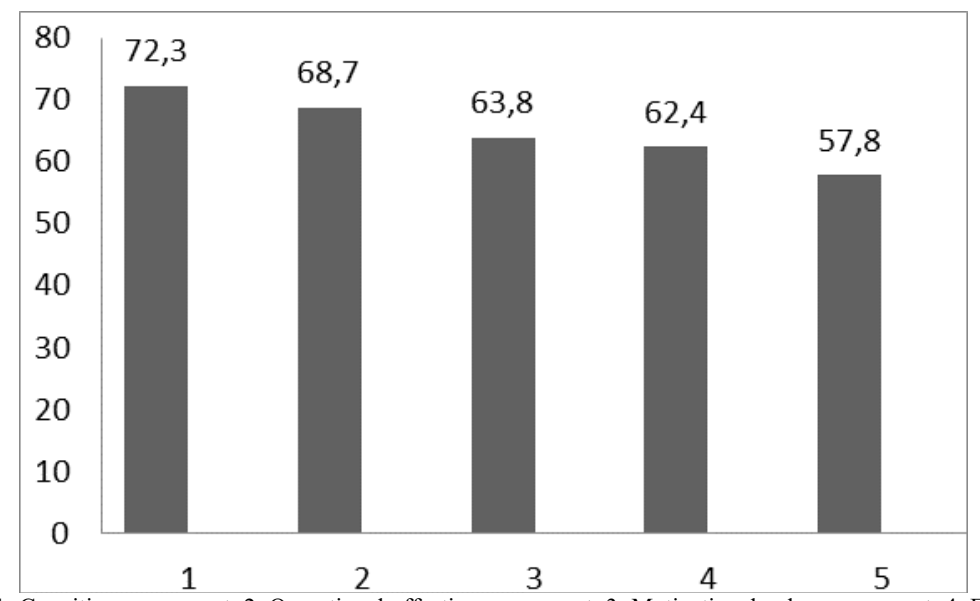

Conventional signs: 1. Cognitive component. 2. Operational-effective component. 3. Motivational value component. 4. Emotional component. 5. The reflective component.

Figure 2. The initial level of future teachers' PCFLC components

In group of students with the high level of foreign language proficiency according to the expert evaluation of oral and written activity the high level of linguistic and communicative skills were identified. However, only $60,3 \%$ of the first year students and $62,9 \%$ of the second year students demonstrated the high level of the linguistic creativity. $95.5 \%$ of students with a high level of language proficiency demonstrated dominance motivation to language learning, $93.3 \%$ - to mastery of profession.

\section{Conclusion}

Thus, the study identified the structural elements (linguistic, discursive, conversational, pragmatic, information technological, socio-cultural and personal-creative subcompetence) and components (cognitive, operational effective, motivational and value component, reflective) of future teachers' PCFLC. The initial level of such structural elements as linguistic, discursive, conversational, pragmatic, information technological, socio-cultural and personal-creative subcompetence is on advanced level according to the investigated group of students. Strategic subcompetence that reflects the ability to use verbal and nonverbal communicative strategies in light of linguistic communication, as well as the skills associated with the linguistic creativity is in optimal development level that causes the necessity of creating special psychological and pedagogical conditions for their development.

\section{Summary}

The practice of forming future teachers' PCFLC is largely determined by learning activities, forms and methods of engaging students to professional foreign language activities. The contents, forms and methods of work should provide optimal educational space for active, free and creative students' self-development providing variance and openness of the educational process. This view corresponds to the requirements of current state educational standard of teacher training. For students of non-language pedagogical specialties, the subject "Foreign language" is not profiling.

Teachers should clearly understand the role and place of foreign language in their life and future professional work, so the process of professional and communicative competence development will be effective and purposeful. The subject "Foreign language", 
being outside the sphere of direct relevant interests, acts as a tool of studying another subject area that causes a need for clarifying its content at the pedagogical university.

It is necessary to remove the discrepancy between: the increasing importance of students' practical foreign language in light of international educational space integration, the requirements of teacher professional standard and the "knowledge technology" of professionally communicative competence development. While learning the students to a greater extent master those competence components that are associated with the mastery of knowledge, the ability to operate them in foreign-professional communication, the ability to self-regulate educational and professional activities. The subject "Foreign Language" has the potential to develop professional and personal qualities of future specialists (communication, reflexivity, tolerance, ability to overcome a psychological barrier in communication, etc.) and their unsatisfactory in professional training. So, PCFLC reflective component as the ability to plan and monitor the intermediate and final results, the adequacy of self-assessment and assessing success of educational activities on subjective criteria, the autonomy performing tasks definitely needs further development.

\section{References}

1. Andriyenko, A.S. Development of the foreign language professional communication competence in students of a technical college (on the basis of the credit modular system of education): abstract of the Thesis of Candidate of Pedagogical Sciences: 13.00.08/ Andriyenko Anzhela Sergeyevna. - Rostov-on-Don, (2006).

2. Baguzina, E.I. Web-quest technology as the didactic method of formation of the foreign language communication competence: by the example of the students of a nonlinguistic university, $\mathrm{PhD}$ thesis, Moscow State University, Moscow, (2012).

3. Federal state education standard of higher education according to the degree program 44.03.01 Pedagogical education (qualification (degree) "bachelor") (approved by the order of the Ministry of Education and Science of the Russian Federation $\mathrm{d} / \mathrm{d}$ December 04, 2015 N 1426); URL:http://fgosvo.ru/uploadfiles/fgosvob/440301.pdf (access date 22.12.2016)

4. Galimzyanova, I.I. Pedagogical system of formation of the foreign language competence of future engineers: abstract of the Thesis of Doctor of Pedagogical Sciences: 13.00.08. - Kazan, (2009).

5. Ilyazova, M.D. Formation of invariants of the professional competence of students sociologists: situational-context approach: methodological guidelines for teachers. Astrakhan, P.48, (2009).

6. Kabardov, M.K. Concerning diagnostics of the foreign language capabilities. Psychological and psychophysiological speech studies. Moscow, Nauka, PP. 176-202, (1985).

7. Khutorskoy, A. V. The key competences and education standards [Digital resource] / A. V. Khutorskoy; Center of distance education 'Eidos', Internet-magazine 'Eidos'. (2002). Access mode: http:// www.eidos.ru/journal/ 2002/0423.htm.

8. Kostyukova, T.A. and Morozova, A.L. Development of the foreign language communication competence in students of non-linguistic colleges. Tomsk: Publishing House of the Tomsk Polytechnic University, P. 119, (2011).

9. Kurpesheva, A.I. Invariants of the foreign language communication competence in students of a technical college. Journal of AGTU. \#1: 87-90, (2011).

10. Lukyanova, M.I. and Kalinina, N.V. Psychological-pedagogical indicators of the school activity: criteria and diagnostics. Moscow SC Sphere. P. 208, (2004).

11. Mikhaylova, E.B. Formation of the professional foreign language competence in students of the engineering specialties with the use of the information and 
communication technologies: abstract of the Thesis of Candidate of Pedagogical Sciences: 13.00.08. Nizhny Novgorod, (2012).

12. Morosanova, V.I. Individual self-regulation style in the random human activity. Psychological journal. \# 4: PP. 26-35, (1995).

13. Nikitina, E.G. Development of the foreign language competence of the university students by means of the modular education: by the example of the economic specialties: Thesis of the Candidate of Pedagogical Sciences: 13.00.08. Cheboksary, P. 292. Journal of Language and Literature, (2010). ISSN: 2078-0303, Vol. 6. No. 3. Iss. 1, August, 2015 | 41

14. Order of the Ministry of Labor and Social Security of the Russian Federation №544n $\mathrm{d} / \mathrm{d}$ October 18, 2013. "Concerning approval of the professional standard "Pedagogue" (pedagogical activity in the sphere of the preschool, primary and secondary education) (kindergartener, teacher) http://www.rosmintrud.ru/docs/mintrud/ orders/129

15. Panfilov, A.N., V.M. Panfilova. Linguistic aptitude of students as the foundation for creation of the foreign language educational space. Nauka i mir, \#3(7) (Volume 3): 8790, (2014).

16. Panfilova V.M., Panfilov A.N., Merzon E.E. Organizational-Pedagogical Conditions to Form the Foreign Competence in Students with the Features of Linguistic Giftedness. International Education Studies, Vol. 8, \#. 2: 176 - 185; (2015). ISSN 1913-9020 EISSN 1913-9039. doi:10.5539/ies.v8n2p176 URL: http://dx.doi.org/10.5539/ ies.v8n2p176 (access date 1.04.2015)

17. Proshyants, N.A. Formation of the foreign language linguistic competences within the professional discourse / N.A. Proshyants // Research work. - \# 3 - PP. 34-38, (2010).

18. Zimnyaya, I.A. Competency-based approach. What is its place in the system of modern approaches to the issues of education? (Theoretical-methodological aspect). Higher education today, \#8: 20-26, (2006). 